\title{
Islet Amyloid in Type 2 (Non-Insulin-Dependent) Diabetes is Related to Insulin
}

\author{
P. Westermark and E. Wilander \\ Department of Pathology, University of Uppsala, Uppsala, Sweden
}

\begin{abstract}
Summary. Amyloid deposition is the most typical islet alteration in Type 2 (non-insulin-dependent) diabetes. In the present study we show by immunohistochemistry that the amyloid reacts with an antiserum against insulin B chain. Islet amyloid was also purified, dissolved in guanidine- $\mathrm{HCl}$ and gel filtered on a Sepharose 6B column. Immunization of a guinea pig with a high molecular weight fraction from this gel filtration
\end{abstract}

resulted in an antiserum with insulin-binding capacity. This binding was partially blocked with pure insulin $B$ chain. The results indicate that islet amyloid contains insulin $B$ chain and that the amyloid is a product of the islet B cells. Thus the study support previous morphological studies.

Key words: Insulin B chain, immunohistochemistry
Amyloid deposits consist of fine fibrils, which are built up by low molecular weight proteins in $\beta$-pleated sheet conformation [1]. Most important properties of the amyloid, such as resistance to enzymes and green birefringence after staining with Congo red, are explained by this conformation. Several different proteins have been shown to contribute to amyloid fibrils. These are: (a) homogeneous immunoglobulin light chains and/or their variable segments in primary and myeloma associated amyloidosis [2], (b) protein AA in reactive (secondary) systemic amyloidosis [3], (c) pre-albumin or a pre-albumin-related protein in several forms of hereditary systemic amyloidosis and in senile cardiac amyloidosis [4, 5], and (d) a calcitonin-related protein in the amyloid of medullary carcinoma of the thyroid [6].

Hyalinization is the most typical alteration of the pancreatic islets in old people with Type 2 (non-insulindependent) diabetes mellitus [7-10]. In this condition a hyaline material is deposited interstitially in the islets and is accompanied by a gradual loss of islet cells, especially the B cells [11, 12]. It has long been agreed that this material is a form of amyloid [8,10,13]. It has been suspected that the amyloid fibrils in the pancreatic islets and in insulinomas are formed by insulin [1], C-peptide [13] or some part of the preproinsulin molecule [14]. In the present paper, we show, using an immunoperoxidase method, that antiserum against insulin B chain binds to islet amyloid, while antiserum against $A$ chain or insulin does not. We show, futhermore, that immuni- zation of a guinea pig with a high molecular weight fraction of a partially purified islet amyloid resulted in an insulin-binding antiserum.

\section{Material and Methods}

Pancreatic tissue from patients with Type 2 diabetes was obtained at autopsies performed within $12 \mathrm{~h}$ after death. Pieces from the tail of the pancreas were fixed in Bouin's solution and embedded in paraffin. For examination of amyloid, sections were stained with Congo red and viewed in polarized light. The rest of the tail and the body of the pancreas was stored at $-20^{\circ} \mathrm{C}$ until used for purification of amyloid. Pancreatic tissue from six patients with heavy islet amyloidosis was used in the study (Table 1).

Table 1. Patients with Type 2 diabetes from whom pancreatic tissue with heavy islet amyloidosis was used in the study

\begin{tabular}{|c|c|c|c|c|}
\hline $\begin{array}{l}\text { Case } \\
\text { Number }\end{array}$ & Sex & $\begin{array}{l}\text { Age at } \\
\text { death } \\
\text { (years) }\end{array}$ & $\begin{array}{l}\text { Duration } \\
\text { of diabetes } \\
\text { (years) }\end{array}$ & Treatment \\
\hline 1 & F & 71 & 22 & $\begin{array}{l}\text { Chlorpropamide }+ \\
\text { metformin }\end{array}$ \\
\hline 2 & $M$ & 68 & 10 & $\begin{array}{l}\text { Chlorpropamide }+ \\
\text { metformin }\end{array}$ \\
\hline 3 & M & 82 & 16 & Diet \\
\hline 4 & $\mathrm{~F}$ & 91 & $?$ & $?$ \\
\hline 5 & $\mathrm{M}$ & 79 & $\begin{array}{l}\text { Recently } \\
\text { discovered }\end{array}$ & None \\
\hline 6 & $\mathrm{M}$ & 77 & 7 & $\begin{array}{l}\text { Unknown oral } \\
\text { antidiabetic drug }\end{array}$ \\
\hline
\end{tabular}




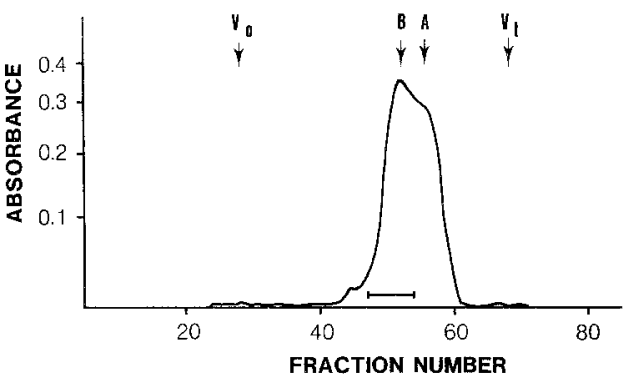

Fig. 1. Bovine insulin dissolved in guanidine $\mathrm{HCl}(6 \mathrm{~mol} / \mathrm{l})$ in $0.1 \mathrm{~mol} / 1$ Tris $\mathrm{HCl}$ buffer $(\mathrm{pH} 8.0)$ containing $0.2 \%$ EDTA and $0.1 \mathrm{~mol} / 1$ dithiothreitol and gel filtered on a Sepharose $6 \mathrm{~B}$ column. $V_{0}=$ void volume and $V_{1}=$ total volume of the column. Insulin is cleaved into its $\mathrm{B}$ chain $(B)$ and $\mathrm{A}$ chain $(A)$. The bar indicates the fraction used for immunization ( $\mathrm{B}$ chain-rich insulin fraction)

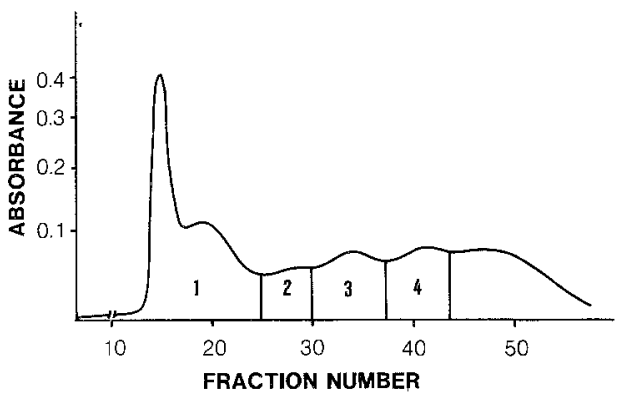

Fig. 2. Purified islet amyloid dissolved and gel filtered as in Fig. 1. The fractions 1-4 were used for immunization

Table 2. Binding of ${ }^{125}$ I-labelled insulin $(3000 \mathrm{cpm})$ to antisera against insulin, a B chain-rich insulin fraction, pure insulin B chain and islet amyloid material (zone 1 in Fig. 2) without and after incubation with pure insulin $B$ chain or with insulin

\begin{tabular}{lrrrr}
\hline \multirow{2}{*}{$\begin{array}{l}\text { Pre-incu- } \\
\text { bation }\end{array}$} & Insulin & $\begin{array}{l}\text { B chain-rich } \\
\text { insulin fraction }\end{array}$ & B chain & $\begin{array}{l}\text { Islet amyloid } \\
\text { material }\end{array}$ \\
\hline None & 2151 & 2161 & 2178 & 2087 \\
B chain & 2169 & 2281 & 1852 & 474 \\
Insulin & 81 & 234 & 108 & 86 \\
\hline
\end{tabular}

Results (cpm) are the mean of two determinations

\section{Amyloid Purification and Gel Filtration}

An amyloid-rich material, which contained at least $25 \%$ of amyloid, was obtained from pancreases containing islets filled with amyloid, using a slight modification of the method by Pras et al. [15]. Briefly, the pancreatic tissue was homogenized repeatedly in normal saline until all soluble proteins had disappeared. The residue was in some cases digested with pepsin [16]. The residual insoluble material, which contained amyloid and some other tissue components, was lyophilized and then treated with guanidine $\mathrm{HCl}(6 \mathrm{~mol} / 1)$ in $0.1 \mathrm{~mol} / 1$ Tris$\mathrm{HCl}$ buffer ( $\mathrm{pH} 8.0$ ) containing $0.2 \%$ EDTA and $0.1 \mathrm{~mol} / \mathrm{l}$ dithiothreitol. After centrifugation (21,000 $\mathrm{xg}$ for $1 \mathrm{~h}$ ), the dissolved material was gel-filtered on a Sepharose $6 \mathrm{~B}$ column equilibrated with guanidine $\mathrm{HCl}(5 \mathrm{~mol} / 1)$ in distilled water and eluted with the same solution under continuous registration of the absorbancy at $280 \mathrm{~nm}$. Fractions were pooled, dialysed exhaustively against distilled water and lyophilized.

\section{Antisera}

Guinea pigs were immunized by intradermal injections bimonthly of the antigens mixed with Freund's complete adjuvant. The animals were bled by heart puncture 2 weeks after the third injection. Bovine insulin obtained from AB Vitrum, Stockholm, Sweden, oxidied bovine insulin A chain from Sigma Chemicals, Saint Louis, Missouri, USA and oxidied bovine insulin B chain from Boehringer, Mannheim, FGR were used as antigens. The purity of the insulin A and B chain was ascertained by isoelectric focussing and by amino-acid analysis. Insulin was also dissolved in guanidine $\mathrm{HCl}(5 \mathrm{~mol} / \mathrm{l})$ in $0.1 \mathrm{~mol} / 1$ Tris- $\mathrm{HCl}$ buffer ( $\mathrm{pH} 8.0$ ) containing dithiothreitol $(0.1 \mathrm{~mol} / \mathrm{l})$ and gel-filtered as above. This resulted in a major retarded double peak and the first half of this peak, mainly containing insulin B chain, was used as antigen (Fig. 1). The four major zones of one islet amyloid gel filtration (Fig. 2) were also used for immunization.

\section{Binding Experiments}

Guinea pig antisera were tested for the presence of insulin binding antibodies by gel filtration. Serum $(5-10 \mu \mathrm{l})$ was incubated with a tracer amount of ${ }^{125} \mathrm{I}$-labelled insulin (Pharmacia, Uppsala, Sweden) overnight at room temperature and gel-filtered on a $1.6 \times 70 \mathrm{~cm}$ Sephacryl S300 column equilibrated with $0.1 \mathrm{~mol} / 1$ Tris $\mathrm{HCl}$ buffer $(\mathrm{pH} 8.0$ ). The elution was performed under continuous registration of the $a b-$ sorbance at $280 \mathrm{~nm}$ and $1.5 \mathrm{ml}$ fractions were collected and counted in a Gamma-guard gammacounter (Gamma-guard, Tracerlab, Brussels, Belgium). In inhibition experiments the same antisera $(5 \mu l)$ were incubated overnight with insulin $(1$ and $2.5 \mathrm{mg} / \mathrm{ml})$, insulin $A$ chain $(1$ and $5 \mathrm{mg} / \mathrm{ml}$ ), insulin $B$ chain $(1$ and $5 \mathrm{mg} / \mathrm{ml}$ ) and various fractions of the gel filtered amyloid-rich material $(1-10 \mathrm{mg} / \mathrm{ml})$. The antisera were then incubated overnight with a tracer amount of ${ }^{125} \mathrm{I}$-labelled insulin and finally with protein A-Sepharose CL-4B (Pharmacia, Uppsala, Sweden). After repeated washing and centrifugation, the sediment was counted in a Gamma-guard gammacounter.

\section{Immunohistochemical Staining}

The antisera obtained were applied to deparaffinized and hydrated sections (about $4 \mu \mathrm{m}$ ) of human pancreatic tissue rich in insular amyloid. For visualization of the antibodies, the peroxidase - antiperoxidase (PAP) technique of Sternberger [17] was used. The primary antibodies were serially diluted 1:50 - 1:1600 before use. Controls were run as recommended and included sections incubated with antiserum inactivated by the addition of antigen in excess $(100 \mu \mathrm{g} / \mathrm{ml}$ diluted antiserum)

\section{Results}

Gel filtration in guanidine $\mathrm{HCl}(5 \mathrm{~mol} / \mathrm{l})$ of amyloidrich pancreatic material resulted in several zones (Fig.2). Gel electrophoresis in the presence of sodium dodecylsulphate and thin layer isoelectric focussing (unpublished data) revealed many bands in each fraction. These findings and the small amount of material available made direct chemical characterization of the islet amyloid impossible.

\section{Binding Experiments}

Anti-insulin and anti-B chain antisera both bound ${ }^{125} \mathrm{I}-$ labelled insulin as revealed by gel filtration. The results of the inhibition experiments are shown in Table 2. Preincubation with insulin $B$ chain inhibited the binding of 


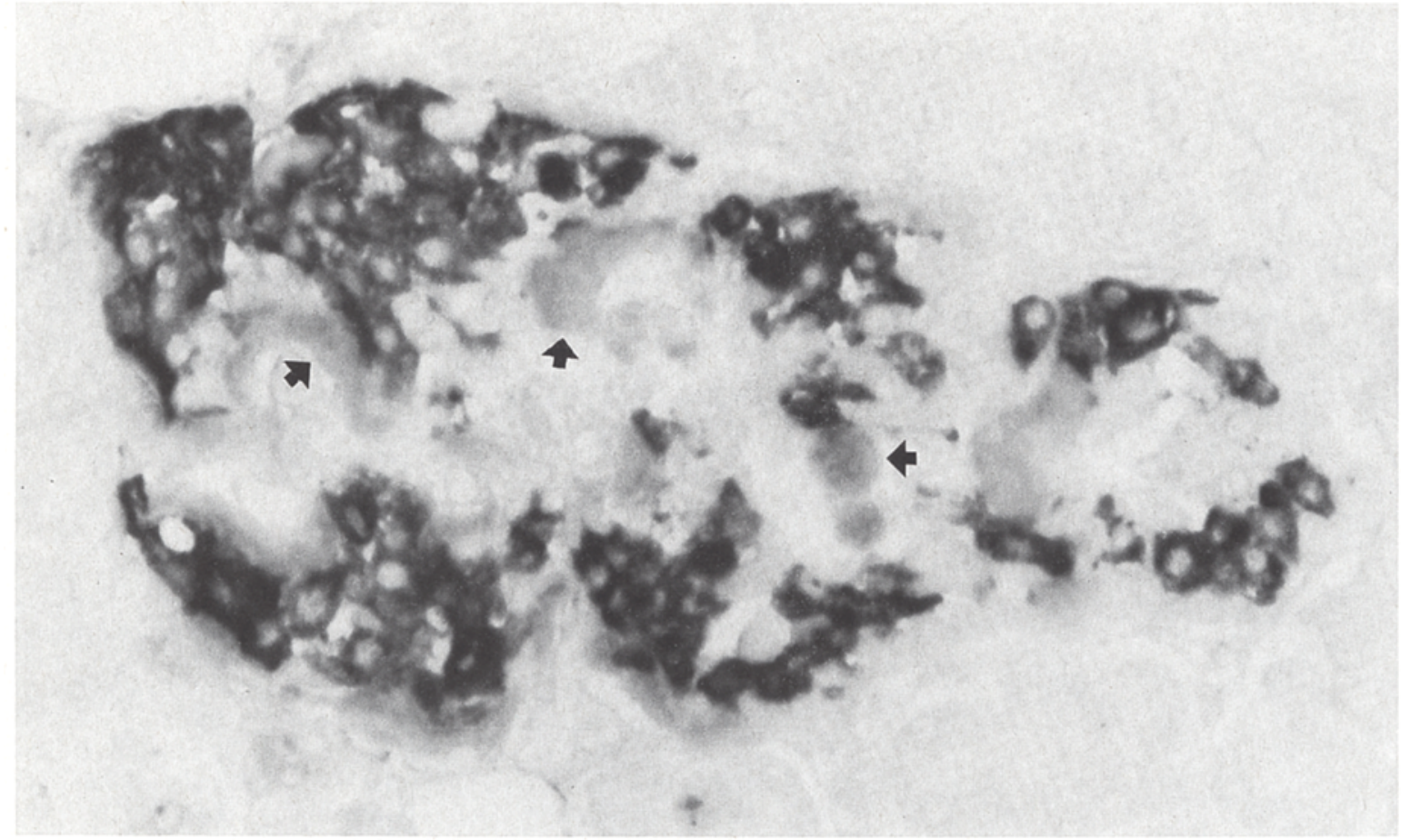

Fig. 3. Islet of Langerhans with amyloid deposits. The section is stained with the peroxidase-antiperoxidase method using guinea pig anti-B chainrich insulin fraction antiserum. The amyloid (arrows) is clearly positive but not as strongly stained as the B cells $(\times 500)$

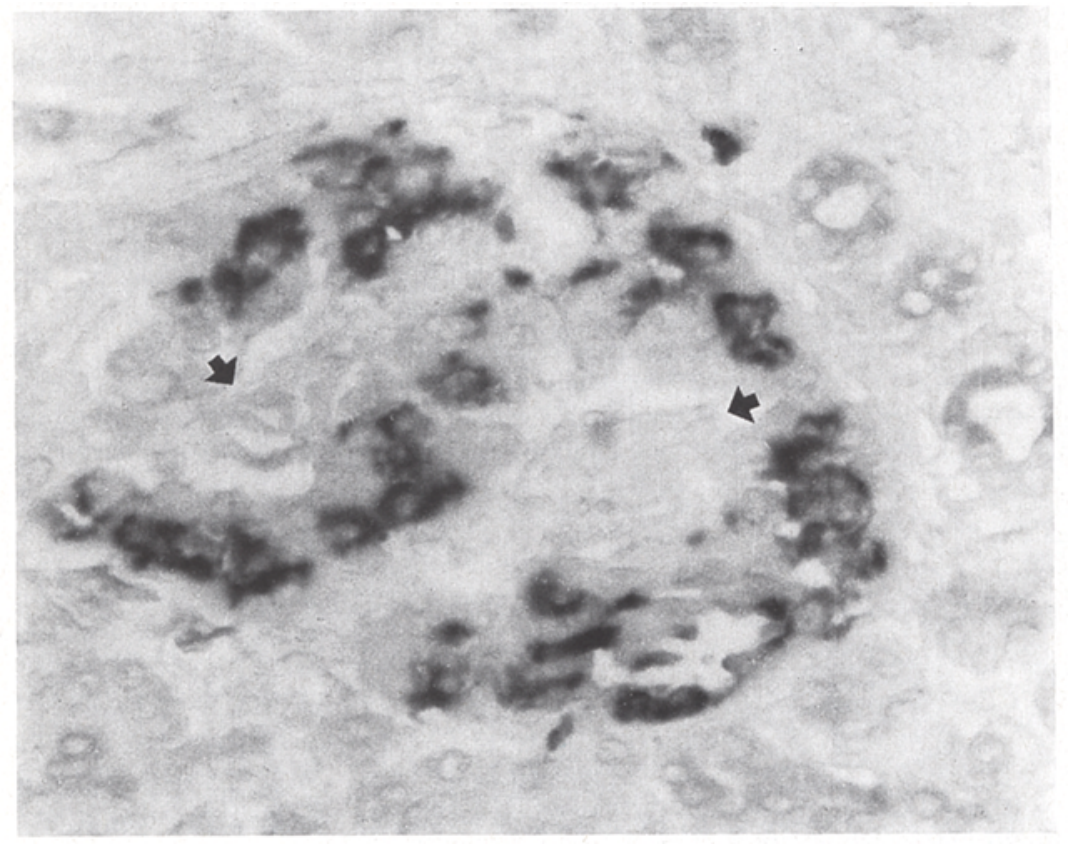

Fig.4. Islet of Langerhans with amyloid deposits. The section is stained as in Figure 3 but the antiserum was at first absorbed with pure insulin B chain. The $\mathbf{B}$ cells are still stained but the amyloid (arrows $)$ is negative $(\times 500)$
${ }^{125}$ I-labelled insulin to the anti-B chain antiserum slightly but did not affect the binding of insulin to the anti-insulin antiserum. Pre-incubation with cold insulin inhibited the binding of ${ }^{125} \mathrm{I}$-insulin to both these antisera. Antiserum obtained by immunization with the B chain rich insulin fraction behaved like the anti-insulin antiserum in this system.

Sera from the guinea pigs immunized with zone 1 or zone 4 material from the gel filtration of islet amyloid both bound insulin, while the sera from the two guinea pigs immunized with zones 2 or 3 material did not. The insulin-binding capacity of anti-zone 4 antiserum was very low and this antiserum was not studied in detail, while anti-zone 1 antiserum was used for further characterization. Pure B chain reduced the binding of insulin to anti-zone 1 antiserum by about $80 \%$. Pre-incubation with insulin inhibited the binding of ${ }^{125}$ I-labelled insulin to this antiserum completely. Pre-incubation of 
anti-zone 1 antiserum with insulin A chain did not inhibit the binding capacity of insulin significantly.

\section{Immunohistochemical Findings}

Immunoperoxidase staining of pancreatic tissue with antisera to insulin, insulin A chain, insulin B chain and the $B$ chain rich insulin fraction all resulted in a strong reaction with the islet $B$ cells while other cells were unstained (Fig. 3). The amyloid showed no reaction products at all after incubation with anti-insulin antiserum or anti-A chain antiserum. Staining with the antiserum against the $B$ chain-rich insulin fraction, however, resulted in a definite reaction with the islet amyloid (Fig.3). This reaction with the amyloid was completely blocked when the antiserum was pre-incubated with insulin $B$ chain but the reaction with the B cells was not abolished (Fig. 4). Staining with anti-B chain antiserum also resulted in a clear but weak reaction with the islet amyloid. The amyloid staining was optimal in the same dilutions (1:200 to 1:800) that were optimal for the staining of the B cells.

Staining of pancreatic tissue with antiserum against zone 1 material of gel filtered islet amyloid resulted in a weak reaction with the islet cells but not with the islet amyloid. No reaction with any other tissue component was seen.

\section{Discussion}

There is a strong evidence that the amyloid of the pancreatic islets is a product of the B cells. Thus there is a close electron microscopical relationship between the amyloid fibrils and the B cells [18]. Furthermore, amyloid is very common in insulin-producing tumours but not in other islet cell tumours [19]. Indirect evidence for a hormone origin is that the amyloid of the medullary carcinoma of the thyroid consists of a calcitonin-like protein, probably procalcitonin [6]. It therefore follows that the islet amyloid might consist of a protein related to insulin or its precursors.

The present study shows that antibodies directed towards antigenic determinants of the insulin B chain react with islet amyloid. Why antiserum against the $B$ chain-rich fraction of insulin reacted more strongly than anti-pure B chain antiserum and why anti-insulin antiserum did not react at all is not completely understood and cannot be solved until we know the exact composition of the islet amyloid. It is, however, possible that the $\beta$-pleated sheet conformation of the amyloid [1] alters the antigenic properties of the amyloid protein. Furthermore, it is possible that the islet amyloid does not contain intact insulin B chain but only fragments of this polypeptide comparable to the situation in immunoglobulin light chain derived amyloidosis, where the fibrils usually consist of the variable segment of a light chain [2]. Finally, antiserum against insulin does not react with insulin A chain and only weakly or not at all with insulin B chain [20,21].

Since insulin biosynthesis can be stimulated by glucose independently of the stimulation of insulin secretion [22], it is possible that in Type 2 diabetes there is at least sometimes a relative over-production of insulin due to the partial inability of the B cells to secrete insulin [23]. If such a synthesis occurs in spite of a defective release of insulin, the synthesized product fills the cell and escapes or is released, e.g. as proinsulin. Such a pathological pathway might lead to polypeptides with a tendency to form fibrils, i.e. amyloid. Insulinomas, which very often produce amyloid [19], regularly secrete proportionally abnormal amounts of proinsulin [24-26] and a slight overproduction of proinsulin has been reported in Type 2 diabetes [26]. It is also possible that insulin, instead of being released, is degraded intracellularly. Different tissues, including the islets of Langerhans, can degrade insulin $[27,28]$ in a sequence of two events. Insulin is first cleaved into its two component chains, which thereafter are degraded into smaller parts. During this degradation some large aggregates are formed, which consist of A and B chains with a molar ratio of about 1:3 [29]. Such aggregates might be converted to fibrils which could explain why they are further degraded only very slowly. Insulinomas, which often form amyloid, are able to split insulin into its two component chains but seem to lack the ability for further degradation [30].

The nature of the high molecular weight insulin-related component of islet amyloid is unclear. Since it retained its high molecular weight in dissociating conditions and in the presence of reducing agents, it is probably composed of polypeptide chains kept together by covalent bonds which are not disulphide-bridges. Covalently bound immunoreactive insulin material of unknown composition and of high molecular weight is often found in insulin preparations [31]. Furthermore, extracts from insulinomas sometimes contain a high molecular weight insulin immunoreactive material [24, 25]. Such material is also sometimes found in the serum of patients with insulinomas $[32,33]$ and in the media when insulinomas are kept in tissue culture [25]. This material could be aggregated insulin, proinsulin or, perhaps, other parts of pre-proinsulin.

Acknowledgements. Supported by the Swedish Medical Research Council (Project nos. 5941 and 102) and the Research Fund of King Gustaf V. Thanks are due to A. Bedy, G. Nilsson and C. Tengvar for skilled technical assistance.

\section{References}

1. Glenner GG, Eanes ED, Bladen HA, Linke RP, Termine D (1974) $\beta$-pleated sheet fibrils: a comparison of native amyloid with synthetic protein fibrils. J Histochem Cytochem 22: 1141-1158

2. Glenner GG, Terry W, Harada M, Isersky C, Page D (1971) Amyloid fibril proteins: proof of homology with immunoglobulin light chains by sequence analysis. Science 172: 1150-1151 
3. Benditt EP, Eriksen N, Hermodson MA, Ericsson LH (1971) The major proteins of human and monkey amyloid substance: common properties including unusual $\mathrm{N}$-terminal amino acid sequences. FEBS Lett 19: 169-173

4. Costa PP, Figueira AS, Bravo FR (1978) Amyloid fibril protein related to prealbumin in familial amyloidotic polyneuropathy. Proc Natl Acad Sci USA 75: 4499-4503

5. Sletten K, Westermark P, Natvig JB (1981) Senile cardiac amyloid is related to pre-albumin. Scand J Immunol 12: 503-506

6. Sletten K, Westermark P, Natvig JB (1976) Characterization of amyloid fibril proteins from medullary carcinoma of the thyroid. $J$ Exp Med 143: 993-998

7. Opie EL (1900) On relation of chronic interstitial pancreatitis to the islands of Langerhans and to diabetes mellitus. J Exp Med 5: $397-428$

8. Ehrlich JC, Ratner IM (1961) Amyloidosis of the islets of Langerhans. A restudy of islet hyalin in diabetic and non-diabetic individuals. Am J Pathol 38: 49-59

9. Bell ET (1952) Hyalinization of the islets of Langerhans in diabetes mellitus. Diabetes 1: 341-344

10. Westermark $P(1971)$ Mast cells in the islets of Langerhans in insular amyloidosis. Virchows Arch Abt A 354: 17-23

11. Westermark P, Grimelius L (1973) The pancreatic islet cells in insular amyloidosis in human diabetic and non-diabetic adults. Acta Path Microbiol Scand (Sect A) 81:291-300

12. Westermark P, Wilander E (1978) The influence of amyloid deposits on the islet volume in maturity onset diabetes mellitus. Diabetologia 15: 417-421

13. Pearse AGE, Ewen SWB, Polak JM (1972) The genesis of apudamyloid in endocrine polypeptide tumours: histochemical distinction from immunamyloid. Virchows Arch (Abt B) 10:93-107

14. Cornwell III GG, Westermark P (1980) Senile amyloidosis: a protean manifestation of the aging process. J Clin Path 33: 1146-1152

15. Pras M, Schubert M, Zucker-Franklin D, Rimon A, Franklin EC (1968) The characterization of soluble amyloid prepared in water. J Clin Invest 47: 924-933

16. Westermark P (1975) Amyloid of human islets of Langerhans. 1. Isolation and some characteristics. Acta Path Microbiol Scand (Sect C) $83: 439-446$

17. Stemberger LA (1974) Immunocytochemistry. Prentice-Hall, Englewood Cliffs, New Jersey, USA

18. Westermark P (1973) Fine structure of islets of Langerhans in insular amyloidosis. Virchows Arch (Abt A) 359:1-18

19. Westermark P, Grimelius L, Polak JM, Larsson L-I, van Noorden S, Wilander E, Pearse AGE (1977) Amyloid in polypeptide hormone-producing tumors. Lab Invest 37: 212-215

20. Varandani PT (1967) Studies on the nature of antigenicity of A and $B$ chains of bovine insulin. Biochemistry $6: 100-104$

21. Yagi Y, Maier P, Pressman D (1965) Antibodies against the component polypeptide chains of bovine insulin. Science 147: 617619
22. Steiner DF, Kemmler W, Clark JL, Oyer PE, Rubenstein AH (1972) The biosynthesis of insulin. In: Greep RO, Astwood EB, Steiner DF, Freinkel N, Geiger SR (eds) Handbook of physiology. Section 7: Endocrinology. Vol 1. Endocrine pancreas. American Physiological Society, Washington, pp 175-198

23. Cerasi E, Luft R (1976) Insulin secretion and the development of diabetes mellitus in the adult. In: Luft R (ed) Insulin. Acta Med Scand (suppl 601) pp 111-148

24. Melani F, Ryan WG, Rubenstein AH, Steiner DF (1970) Proinsulin secretion by a pancreatic beta-cell adenoma. Proinsulin and Cpeptide secretion. N Engl J Med 283:713-719

25. Pipeleers DG, Levy J, Malaisse-Lagae F, Malaisse WJ (1975) In vitro biosynthesis and release of three immuno-reactive insulinlike components by a human insulinoma. Diab Metabol 1:7-11

26. Rainbow SJ, Woodhead JS, Yue DK, Luzio SD, Hales CN (1979) Measurement of human proinsulin by an indirect two-site immunoradiometric assay. Diabetologia 17:229-234

27. Kohnert K-D, Hahn H-J, Zühlke H, Schmidt S, Fiedler H (1974) Breakdown of exogenous insulin by Langerhans islets of the pancreas in vitro. Biochim Biophys Acta 338: 68-77

28. Kohnert K-D, Jahr H, Schmidt S, Hahn H-J, Zühlke H (1976) Demonstration of insulin degradation by thiol-protein disulfide oxidoreductase (glutathione-insulin transhydrogenase) and proteinases of pancreatic islets. Biochim Biophys Acta 422: 254-259

29. Varandani PT (1973) Insulin degradation. IV. Sequential degradation of insulin by rat kidney, heart and skeletal muscle homogenates. Biochim Biophys Acta 295: 630-636

30. Varandani PT (1974) Insulin degradation in insulinoma: evidence for the occurrence of an inactive form of glutathione-insulin transhydrogenase and for the absence of insulin A and B chains degrading protease(s). Biochem Biophys Res Commun 60: 11191126

31. Nolan C, Margoliash E, Peterson JD, Steiner DF (1971) The structure of bovine proinsulin. J Biol Chem 246: 2780-2796

32. Nunes-Correa J, Lowy C, Sönksen PH (1974) Presumed insulinoma secreting a high-molecular-weight insulin analogue. Lancet 1:837-841

33. Yalow RS, Berson SA (1973) 'Big, big insulin'. Metabolism 22: $703-713$

Received: 5 July 1982

and in revised form: 3 November 1982

Dr. P. Westermark

Department of Pathology

University Hospital

S-751 85 Uppsala

Sweden 